\title{
Corporate Board Diversity and Sustainability Reporting: A Study of Selected Listed Manufacturing Firms in Nigeria
}

\author{
Helen Obiageli Anazonwu1, Francis Chinedu Egbunike²*, Ardi Gunardi³ \\ ${ }^{1}$ Nnamdi Azikiwe University, Faculty of Management Sciences, Awka, Nigeria \\ ${ }^{2}$ Nnamdi Azikiwe University, Faculty of Management Sciences, Awka, Nigeria \\ 3 Universitas Pasundan, Faculty of Economics and Business, Bandung, Indonesia \\ *Correspondence to: Francis Chinedu Egbunike, Nnamdi Azikiwe University, \\ Department of Accountancy, Faculty of Management Sciences, PMB 5025, Awka, \\ Anambra State, Nigeria. \\ E-mail: cf.egbunike@unizik.edu.ng
}

\begin{abstract}
The objective of the study is to ascertain the influence of corporate board diversity on sustainability reporting on a sample of quoted manufacturing firms in Nigeria. The study adopts a panel research design. The population of the study comprised quoted manufacturing companies on the Nigerian Stock Exchange. This was restricted to companies classified under conglomerates, consumer goods, and, industrial goods sector. The study used secondary data, extracted from the annual reports of the studied manufacturing companies. Fixed effects panel regression analysis was used to test the hypotheses. The dependent variable sustainability reporting was measured using an Economic, Social, and Governance (ESG) index, the independent variables were board member nationality, proportion of women directors, proportion of non-executive directors, and multiple directorships. The results show no significant positive influence of board member nationality, while proportion of women directors, proportion of non-executive directors, and multiple directorships were significant. The study recommends among others, the adoption of NSE Sustainability Disclosure Guidelines for a unified integrated reporting framework for Nigerian firms, secondly, a heterogeneous board composition, which can leverage on the diverse set of skills of board members.
\end{abstract}

Keywords: board diversity, sustainability reporting, women directors, corporate social responsibility.

Article info: Received 28 February 2018; revised 2 May 2018; accepted 20 May 2018

Recommended citation: Anazonwu, H. O., Egbunike, F. C., \& Gunardi, A. (2018). Corporate Board Diversity and Sustainability Reporting: A Study of Selected Listed Manufacturing Firms in Nigeria. Indonesian Journal of Sustainability Accounting and Management, 2(1), 65-78.

DOI: 10.28992/ijsam.v2i1.52

\section{Introduction}

It is the responsibility of a company's board of directors to "oversee the actions and decisions" of management (Rupley et al., 2012). They are the most influential decision-making unit of a corporation (Leung, 2015). There responsibilities span from making key financial and strategic decisions, such as approving changes in capital structure/mergers and acquisitions, to the difficult task of choosing the company's top executive leadership (Ferreira, 2011). The literature identifies four key functions of boards: monitoring and controlling managers, 
providing information and counsel to managers, monitoring compliance with applicable laws and regulations, and linking the corporation to the external environment (Mallin, 2004; Monks \& Minow, 2004).

However, 'given the diversity of expertise, information, and availability that is needed to understand and govern today's complex businesses, it is unrealistic to expect an individual director to be knowledgeable and informed about all phases of business' (Conger \& Lawler III, 2001). Scholars have therefore suggested for board diversity as one of the ways to enhance corporate governance (Leung, 2015). Some scholars refer to board diversity as a demographic phenomenon entailing age, gender, and ethnicity, while others refer to board diversity as a structural phenomenon comprising CEO duality, board independence, and director ownership (Hoang et al., 2016).

Diversity due to differences in gender, ethnicity or cultural background (Arfken, Bellar, \& Helms, 2004) leads to a better understanding of the company's market position, creativity and innovation as well as more effective problem solving (Carter et al., 2003). According to Conger \& Lawler III (2001) "the best boards are composed of individuals with different skills, knowledge, information, power, and time to contribute". Thus, board diversity represents a significant corporate governance (CG) mechanism (Eulerich et al., 2014).

Increased awareness of social, environmental and governance issues has greatly transformed the way business as conducted (Kolk \& van Tulder, 2010; Seuring \& Müller, 2008). Corporations are increasingly pressured to report on additional issues, provided in the form of complementary reports on issues, such as governance, social responsibility and intellectual capital (Rodríguez-Ariza et al., 2012). However, these documents were mostly drafted individually, and so the information provided might overlap; moreover, there could be a lack of coherence in the contents of the various reports generated, which would hamper the decision-making process (Rodríguez-Ariza et al., 2012). Integrated reporting developed out of the desire to integrate all information into a single document, which provides a clear and concise statement, of the organization operations (IIRC, 2011); (Ghani et al., 2018). It is the convergence of reporting architecture (Okaro \& Okafor, 2017), bordering on environmental, social and governance (ESG) issues (Velte, 2017).

Consequently, studies have shown a positive correlation between board diversity and sustainability reporting and performance (Michelon \& Parbonetti, 2012; Post et al., 2011; Rao et al., 2012; Rupley et al., 2012; Webb, 2004). In Nigeria, despite the commitment of the government to gender equality, the practical situation is characterized with sexual stereotyping of social roles, discriminatory traditions and cultural prejudices (Lincoln \& Adedoyin, 2012). This could also be attributed to the national cultural perspective of the country, which places 'men as the leaders of the society' is one of crucial factor which limits female participation in top leadership positions (Şener \& Karaye, 2014). Nigeria is a highly patriarchal society with men dominating, thus women are mostly under-represented in managerial role, because of the socio-cultural traditions which inhibit them (Lincoln \& Adedoyin, 2012). With a greater proportion of female directors, a company would most likely appear ethical and demonstrate good corporate citizenship (Landry et al., 2016). Foreign directors are also known to bring along beneficial attributes to the company, by bringing along their wealth of experience to corporate board rooms (Masulis et al., 2012). Ujunwa et al. (2012) show that board nationality and ethnicity were positive in predicting firm performance among listed firms in Nigeria.

With the growing importance of the sustainability agenda on the business roundtable, with studies confirming that capital markets incorporate environmental, social, and governance data in business valuation models (Eccles et al., 2011; loannou \& Serafeim, 2015). The Nigerian Stock Exchange (NSE) commenced a phased project to integrate sustainability reporting for its listed companies. This resulted in the production of the Sustainability Disclosure Guidelines (SDG), which cover environmental, social and governance (ESG) issues. Presently, 15 Stock Exchanges provide sustainability guidance in their market, 23 has committed to institute (of which the NSE is part of) while 41 have no guidance. However, the state of corporate governance in the country is still at its rudimentary phase (Nwannebuike \& Ike, 2014). 
Despite the influence of board diversity on financial performance and reporting, few studies have examined whether this is also applicable in non-financial performance and reporting (Rao \& Tilt, 2016a). Prior studies have established that internal governance mechanism, which involves the system of rules, practices and processes by which a company is directed and controlled (Ong \& Djajadikerta, 2017), plays a vital role in sustainability reporting and performance (Lau et al., 2016; Garcia-Torea et al., 2016; Walls et al., 2012; Kolk, 2008; Gibson \& O'Donovan, 2007). Studies have investigated the impact of board composition/specific board attributes (e.g., gender diversity) on corporate social responsibility/sustainability and firm performance in developed economies (Jain \& Jamali, 2016; Landry et al., 2016; Malik, 2015; Setó-Pamies, 2015; Ferrero-Ferrero et al., 2015; Sharif \& Rashid, 2014; Zhang et al., 2013; Post et al., 2011; Bear et al., 2010; Bernardi et al., 2006; Sharma \& Henriques, 2005; Carter et al., 2003). However, there is little empirical evidence on the influence of women on the board (Ben-Amar et al., 2017; Leung, 2015; Rodríguez-Ariza et al., 2012) and their role in facilitating the production of integrated sustainability reports in developing countries (Yasser et al., 2017).

Controversy exists on the relationship between the independence of the board and corporate social responsibility (Rodríguez-Ariza et al., 2012). Some studies have shown a positive relationship between nonexecutive directors and corporate social responsibility (Prado-Lorenzo et al., 2009; Cheng \& Courtenay, 2006), others report a negative relationship (Prado-Lorenzo \& Garcia-Sanchez, 2010; Haniffa \& Cooke, 2005) or none at all (Sánchez et al., 2011). The literature also documents mixed findings on the subject of foreign directorship.

In addition, few studies have addressed the issue of multiple directorships in the context sustainability reporting and performance (Ong \& Djajadikerta, 2017). This study therefore seeks to fill this gap by investigating the influence of corporate board diversity on integrated sustainability reporting of selected manufacturing firms in Nigeria. Based on the above research problem, the main objective of this study is to ascertain the influence of corporate board diversity on sustainability reporting of selected quoted manufacturing firms in Nigeria. The specific objectives of the study are as follows: 1) To ascertain the influence of board member nationality on economic, social and governance disclosure. 2) To examine the influence of proportion of women directors on economic, social and governance disclosure. 3) To determine the influence of proportion non-executive directors on economic, social and governance disclosure. 4) To ascertain the influence of multiple directorships on economic, social and governance disclosure.

\section{Methods}

The study adopts the panel research design within the domain of longitudinal research design. Panel research designs are particularly strong in dealing with the threats of unit heterogeneity and temporal instability (Halaby, 2003; Allison, 1994; Hsiao, 2003; Maddala, 1987) and are considered suitable for cause and effect studies.

The population of the study comprises manufacturing companies listed on the Nigerian Stock Exchange (NSE). The companies are classified under 11 sectors, such as: Agriculture; Conglomerates; Construction/Real Estate; Consumer Goods; Financial Services; Healthcare; Information \& Communications Technology (ICT); Industrial Goods; Natural Resources; Oil \& Gas; and, Services (NSE, 2017). However, the scope of the study limited the focus to 3 sectors (Conglomerates, Consumer goods, and, Industrial Goods). The studied companies are listed (Table 1).

The Hausman test was conducted to determine whether the Fixed Effects or Random Effects regression is to be used. It tests the null hypothesis that the coefficients estimated by the random effects estimator are the same as the coefficients estimated by the consistent fixed effects estimator (Hajek et al., 2015). The study used the Fixed Effects (FE) regression. FE regression is a method that is especially useful in the context of causal inference (Gangl, 2010). While standard regression models provide biased estimates of causal effects if there 
are unobserved confounders, FE regression is a method that can (if certain assumptions are valid) provide unbiased estimates in this situation (Brüderl \& Ludwig, 2015).

Table 1 List of Selected Manufacturing Companies

\begin{tabular}{|c|c|c|c|}
\hline No. & Company & No. & Company \\
\hline 1. & A.G. Leventis Nigeria Plc. & 23. & Nigerian Enamelware Plc. \\
\hline 2. & Chellarams Plc. & 24. & Vitafoam Nigeria Plc. \\
\hline 3. & John Holt Plc. & 25 & P.Z. Cussons Nigeria Plc. \\
\hline 4. & SCOA Nigeria Plc. & 26. & Unilever Nigeria Plc. \\
\hline 5. & Transnational Corporation Plc & 27. & Mcnichols Plc \\
\hline 6. & UACN Plc. & 28. & Nascon Allied Industries Plc. \\
\hline 7. & DN Tyre \& Rubber Plc. & 29. & African Paints (Nigeria) Plc. \\
\hline 8. & Champion Breweries Plc & 30. & Austin Laz \& Company Plc. \\
\hline 9. & Golden Guinea Breweries Plc. & 31. & Berger Paints Plc. \\
\hline 10. & Guinness Nigeria Plc. & 32. & Beta Glass Plc. \\
\hline 11. & International Breweries Plc. & 33. & Cap Plc. \\
\hline 12. & Nigerian Breweries Plc. & 34. & Cement Co. of North. Nig. Plc. \\
\hline 13. & 7-up Bottling Company Plc. & 35 & Cutix Plc. \\
\hline 14. & Dangote Flour Mills Plc. & 36. & Dangote Cement Plc. \\
\hline 15. & Dangote Sugar Refinery Plc. & 37. & First Aluminium Nigeria Plc. \\
\hline 16. & Flour Mills Nigeria Plc. & 38. & Greif Nigeria Plc \\
\hline 17. & Honeywell Flour Mill Plc. & 39. & Lafarge Africa Plc. \\
\hline 18. & Multi-trex Integrated Plc & 40. & Meyer Plc \\
\hline 19. & N. Nigeria Flour Mills Plc. & 41. & Paints and Coatings Manufactures Plc. \\
\hline 20. & Union Dicon Salt Plc. & 42. & Portland Paints \& Products Nigeria Plc. \\
\hline 21. & Cadbury Nigeria Plc. & 43. & Premier Paints Plc. \\
\hline 22. & Nestle Nigeria Plc. & & \\
\hline
\end{tabular}

Source: Nigerian Stock Exchange Website

FE estimation builds on the error components model,

$$
y_{i t}=x_{i t} \beta+\alpha_{i}+\varepsilon_{i t}
$$


Where, $y_{i t}$ denotes the observed outcome of firm $i$ at time $t, x_{i t}$ is the $(1 \times K)$ vector of covariates of this firm measured contemporaneously, and $\beta$ is the corresponding $(K \times 1)$ vector of parameters to be estimated. The error term of this model is split into two components. The ai is stable firm specific characteristics which are often unobserved, but also are very often related to the covariates. Hence, the ai are unobserved effects capturing time-constant firm heterogeneity. The second component $\varepsilon_{i t}$ is an idiosyncratic error that varies across firms and over time. The intercept $a$ that is standard in regression models is dropped, due to collinearity with the firm-specific errors $\alpha_{i}$.

$$
E S G_{(i, t)}=\alpha+B M N(i, t)+P W D_{(i, t)}+P N E D_{(i, t)}+M D_{(i, t)}+\operatorname{Size}_{(i, t)}+\mu \ldots(1)
$$

The level of significance was set at $p<0.05$.

Table 2 Description of Variables

\begin{tabular}{|c|c|c|}
\hline Proxy & Variable & Description \\
\hline $\begin{array}{l}\text { Environmental Social } \\
\text { Governance (ESG) }\end{array}$ & $\begin{array}{l}\text { Dependent } \\
\text { variable }\end{array}$ & $\begin{array}{l}\text { Analysed using content analysis. Prior studies have categorised disclosures } \\
\text { into individual aspects (Cho, Michelon, Patten, \& Roberts, 2015); (Guthrie \& } \\
\text { Parker, 1990), the categories considered in the study are: economic, social, } \\
\text { and governance. The items are scored one or zero based on the presence or } \\
\text { absence of a disclosure item. }\end{array}$ \\
\hline $\begin{array}{l}\text { Board Member } \\
\text { Nationality (BMN) }\end{array}$ & $\begin{array}{l}\text { Independent } \\
\text { variable }\end{array}$ & $\begin{array}{l}\text { This is proxied as the number of foreign directors sitting on the board divided } \\
\text { by the total number of directors. }\end{array}$ \\
\hline $\begin{array}{l}\text { Percentage of } \\
\text { Women Directors } \\
\text { (PWD) }\end{array}$ & $\begin{array}{l}\text { Independent } \\
\text { variable }\end{array}$ & $\begin{array}{l}\text { This is proxied as the number of female directors sitting on the board divided } \\
\text { by the total number of directors. }\end{array}$ \\
\hline $\begin{array}{l}\text { Percentage of Non- } \\
\text { Executive Directors } \\
\text { (PNED) }\end{array}$ & $\begin{array}{l}\text { Independent } \\
\text { variable }\end{array}$ & $\begin{array}{l}\text { This is proxied as the number of non-executive directors sitting on the board } \\
\text { divided by the total number of directors. }\end{array}$ \\
\hline $\begin{array}{l}\text { Multiple Directorship } \\
\text { (MD) }\end{array}$ & $\begin{array}{l}\text { Independent } \\
\text { variable }\end{array}$ & $\begin{array}{l}\text { This is proxied as the number of directors serving on more than one board to } \\
\text { the total number of directors on the board (Rupley et al., 2012). }\end{array}$ \\
\hline Size & $\begin{array}{l}\text { Control } \\
\text { variable }\end{array}$ & $\begin{array}{l}\text { This was proxied using the total assets of the firm. Prior studies have shown } \\
\text { the link between firm size and corporate social responsibility (Habbash, } \\
\text { 2016); (Khan, 2010), because larger firms are more salient, thus, tend to } \\
\text { attract more attention from consumers, the media and the general public, } \\
\text { which may compel them to look good (Hyun, Yang, Jung, \& Hong, 2016). }\end{array}$ \\
\hline
\end{tabular}

\section{Results and Discussion}

The Table 3 presents the univariate properties of the data, specifically, mean, median, maximum, minimum, and standard deviation. The average of board member nationality is 0.215 , which shows that approximately $22 \%$ of the directors on the board of manufacturing firms are foreigners. The average proportion of non-executive directors is 0.509 , which shows that approximately $51 \%$ of the directors on the board of manufacturing firms are non-executive directors. The average proportion of women directors is 0.090 , which shows that less than $10 \%$ of the directors on the board of manufacturing firms are females. The average value of multiple directorships is 0.349 , which shows that on the approximate $35 \%$ of the directors of the studied firms sit one or more other boards of the manufacturing firms. 
The correlation matrix of the variables shows a positive correlation between PWD, PNED and MD with Size, but a negative correlation of BMN with Size. PWD is positively correlated with PNED, BMN and MD. PNED is positively correlated with $B M N$ and $M D$. BMN is negatively correlated with $M D$. None of the variables showed a correlation coefficient greater than 0.50 among the independent variables and control variable.

Table 3 Descriptive Statistics

\begin{tabular}{lcccccc}
\hline & BMN & PNED & PWD & MD & ESG & Size \\
\hline Mean & 0.215194 & 0.509607 & 0.090914 & 0.349919 & 1.72 & $97,980,186,062.50$ \\
Median & 0.154762 & 0.625000 & 0.000000 & 0.363636 & 1.00 & $18,500,000,000.00$ \\
Maximum & 0.875000 & 0.916667 & 0.625000 & 0.714286 & 3.00 & $2,104,360,539,000.00$ \\
Minimum & 0.000000 & 0.000000 & 0.000000 & 0.000000 & 0.00 & $-42,217,000.00$ \\
Std. Dev. & 0.236180 & 0.270273 & 0.131317 & 0.189200 & 1.14 & $245,000,000,000.00$ \\
Skewness & 0.832358 & -0.787563 & 1.994306 & -0.403199 & 0.03 & 5.58 \\
Kurtosis & 2.687755 & 2.398880 & 7.752252 & 2.654677 & 1.41 & 39.63 \\
Sum & & & & & & $23,500,000,000,000.00$ \\
Sum Sq. Dev. & 13.33171 & 17.45835 & 4.121376 & 8.555370 & 312.73 & $14,300,000,000,000,000,000,000,000.00$ \\
\hline
\end{tabular}

Table 4 Correlation Matrix of Variables

\begin{tabular}{|c|c|c|c|c|c|}
\hline PWD & PNED & BMN & MD & Size & \\
\hline \multirow[t]{5}{*}{1.0000} & 0.1243 & 0.2415 & 0.0792 & 0.1503 & PWD \\
\hline & 1.0000 & 0.0966 & 0.3423 & 0.0491 & PNED \\
\hline & & 1.0000 & -0.1252 & -0.0599 & BMN \\
\hline & & & 1.0000 & 0.2316 & MD \\
\hline & & & & 1.0000 & Size \\
\hline
\end{tabular}

The FE regression results are shown in the Table 5. FE regression was conducted to test if board diversity significantly predicted economic, social and governance disclosure. The results of the FE regression indicated the three predictors explained $55.3 \%$ of the variance $\left(R^{2}=0.553, F(6,233)=4.12\right.$, $p$-value $\left.<0.05\right)$.

The first hypothesis checked for a significant positive influence of board member nationality on economic, social and governance disclosure. From Table 5, the coefficient of board member nationality is negative and not significant ( $p$-value $0.8584>0.05$ ). The null hypothesis is accepted and the alternate rejected; thus, 'there is no significant positive influence of board member nationality on economic, social and governance disclosure'.

The second hypothesis checked for a significant positive influence of proportion of women directors on economic, social and governance disclosure. From Table 5, the coefficient of proportion of women directors is positive and significant ( $p$-value $0.0025<0.05$ ). The null hypothesis is rejected and the alternate accepted; thus, 
'there is a significant positive influence of proportion of women directors on economic, social and governance disclosure'.

The third hypothesis checked for a significant positive influence of proportion of non-executive directors on economic, social and governance disclosure. From Table 5, the coefficient of proportion of non-executive directors is positive and significant ( $\mathrm{p}$-value $0.0031<0.05$ ). The null hypothesis is rejected and the alternate accepted; thus, 'there is a significant positive influence of proportion of non-executive directors on economic, social and governance disclosure'.

The fourth hypothesis checked for a significant positive influence of multiple directorships on economic, social and governance disclosure. From Table 5, the coefficient of multiple directorships is positive and significant ( $p$-value $0.0044<0.05$ ). The null hypothesis is rejected and the alternate accepted; thus, 'there is a significant positive influence of multiple directorships on economic, social and governance disclosure'.

Table 5 Fixed-Effects Model

\begin{tabular}{|c|c|c|c|c|}
\hline & Coefficient & Std. Error & $\mathrm{t}$ & $\mathrm{p}$-value \\
\hline Const & 1.6399 & 0.208865 & 7.8515 & 0.000 \\
\hline PWD & 1.850713 & 0.606945 & 3.0492 & $0.0025 * * *$ \\
\hline PNED & 1.092776 & 0.291918 & 3.3178 & $0.0031^{* * *}$ \\
\hline BMN & -0.062037 & 0.347488 & -0.1785 & 0.8584 \\
\hline MD & 1.329871 & 0.460081 & 3.7170 & $0.0044 * * *$ \\
\hline Size & $-1.01982 \mathrm{e}-013$ & $3.15035 \mathrm{e}-013$ & -0.3237 & 0.7464 \\
\hline R-squared & 0.590457 & & & \\
\hline$F(6,233)$ & 4.120498 & & & \\
\hline Durbin-Watson & 1.579213 & & & \\
\hline Adjusted R-squared & 0.552979 & & & \\
\hline P-value (F) & 0.043803 & & & \\
\hline
\end{tabular}

Global studies have shown support for board diversity and sustainability reporting (Fernandez-Feijoo et al., 2014); Frias-Aceituno et al., 2013). The study finds no significant positive influence of board member nationality on economic, social and governance disclosure. This is consistent with the study by Huijsmans (2017) on a sample of non-financial firms from Germany, France, Netherlands, Sweden, Switzerland and the UK, finds no evidence of a significant relationship between board-level national culture and CSP of firms and no significant relationship between board nationality diversity and CSP. But, Post et al. (2011) found that boards with a higher proportion of Western European directors were more likely to implement environmental governance structures or processes. The study by Haniffa \& Cooke (2002) in Malaysia which was extended in 2005, indicated found a significant positive correlation between CSR disclosure and foreign ownership. The inclusion of women in boards mediates and moderates the effect of cultural characteristics on CSR reporting (Fernandez-Feijoo et al., 2014). As regards firm performance, studies have shown mixed findings. For instance, 
Carter et al. (2003) find significant positive relationship between the fraction of women or minorities on the board and firm value.

The study finds a significant positive influence of proportion of women directors on economic, social and governance disclosure. This is consistent with the studies by Ong \& Djajadikerta (2017), Nadeem et al. (2017) in Australia; Ben-Amar et al. (2017) in Canada; Yasser et al. (2017) in three Asia Pacific emerging economies (Malaysia, Pakistan, and Thailand); Cabeza-García et al. (2017) in Spain; Nekhili et al. (2017) in France; Jizi (2017), Arayssi et al. (2016) in the UK; and, (Rupley et al., 2012) in US (Nekhili et al., 2017) show that CSR engagement and reporting is more value relevant to the market value of firms with a gender-diverse board than firms with male dominated boards, this according to Jizi (2017) is because female participation on boards favorably affects CSR engagement and reporting and the establishment of ethical policies.

Moreover, the likelihood of voluntary climate change disclosure increases with women percentage on boards (Ben-Amar et al., 2017), and engaging an external assurance provider for CSR reporting is value relevant for firms without female directors but not value relevant for firms with female directors (Nekhili et al., 2017). Gender diverse boards are associated with higher quality sustainability reports (Al-Shaer \& Zaman, 2016). The presence of women on corporate boards favorably influences a firm's risk appetite and performance through promoting a firm's investment in effectual social engagements and reporting on them (Arayssi et al., 2016).

Studies have identified a minimum number of 3 women or more for improved CSR engagement (Post et al., 2011). Fernandez-Feijoo et al. (2014) using data from a survey conducted by KPMG, and the Women on Boards Report from Governance Metrics International, find that boards with three or more women are determinants for CSR disclosure, inform more on CSR strategy and include Assurance statements. Other studies however show contrary findings on the subject. In Indonesia, Handajani et al. (2014) report a negative effect of board gender on corporate social disclosure.

The study finds a significant positive influence of proportion of non-executive directors on economic, social and governance disclosure. This is consistent with studies by Ong \& Djajadikerta (2017) in Australia; Akhtaruddin et al. (2009) in Malaysia, which confirm a positive correlation between the proportion of independent directors and sustainability/voluntary disclosure. Higher board independence can enhance the corporate image of the firm through enhancing societal conscience (Jizi, 2017). Post et al. (2011) finds that a higher proportion of outside board directors were associated with more favorable environmental corporate social responsibility (ECSR) and the natural environment ratings data from Kinder Lydenberg Domini (KLD) Inc. Independent female directors have also been shown to have a greater effect on sustainability reporting quality than non-independent female directors (Al-Shaer \& Zaman, 2016). However, in Australia, Rao \& Tilt (2016b) found that the relationship between independent/non-executive directors and CSR reporting is unclear. Also, Said et al. (2009) report no relationship between board independence and CSR disclosure.

The study finds a significant positive influence of multiple directorships on economic, social and governance disclosure. Similarly, Ong \& Djajadikerta (2017) in Australia show a significant positive correlation between sustainability disclosures and multiple directorships. Also, Rao \& Tilt (2016b) find that multiple directorships influence CSR reporting. Rupley et al. (2012) in US found a significant positive relationship between multiple directorships and company voluntary environmental disclosures. Haniffa \& Cooke (2002) in Malaysia which was extended in 2005 reported a significant positive correlation between CSR disclosure and Chair with multiple directorships.

\section{Conclusion}

The bane of the study is to ascertain the influence of corporate board diversity on integrated sustainability reporting by manufacturing firms in Nigeria. Empirical studies have shown support for boardroom diversity as 
one driver for corporate sustainability. Such diversity could be reflected, in number of female directors, the nationality of the directors which determines their individual beliefs and values, and presence or absence of non-executive directors and multiple directorships, among others. Moreover, integrated sustainability reporting has emerged as new form of reporting on social, economic and governance all in a single document to aid stakeholders makes informed short and long-term decisions. The findings contribute empirical evidence on the influence of board diversity on integrated sustainability reporting of manufacturing firms.

The study makes the following recommendations: 1) The adoption of the NSE Sustainability Disclosure Guidelines for a unified integrated reporting framework for Nigerian firms. The study by Okaro \& Okafor (2017) showed that no single company has reported under the international IR framework, though many companies were reporting under the GRI sustainability reporting framework. However, extant studies have often cited locality of development as a factor affecting adoption, therefore standards developed in western countries were often not suited to African and developing countries. The NSE Sustainability Disclosure Guidelines would encourage the harmonization of sustainability disclosure for firms. 2) Heterogeneous board structure: The study recommends a heterogeneous board in order to leverage on the diverse set of skills brought by board members to decision-making. This can be achieved by encouraging adequate gender representation, encouraging adequate gender representation on the board. A corporate revolution, which involves a change of mindset/approach by board members' in welcoming a more heterogeneous board, as well as to place greater trust in one another and work together more effectively (Leung, 2015). The board recruitment and evaluation process should be such that is dynamic recognizing individual skills and capabilities as against traditional approaches based mainly on experience usually in a particular industry. Such a process may help to reinforce a lack of diversity in perspectives and experiences, as well as (in most companies) in gender and race (Deloitte, 2017). 3) Instituting green initiatives at committee levels: Studies have shown that fragmented boards with dedicated committees often perform better on sustainability programs. The study therefore recommends the institution of sustainability committees for firms desirous of achieving triple bottom line performance. The responsibility of the committee shall include among others, the following: a) Integrating sustainability as part of the overall business strategy; and, b) Creating a sustainable value chain which links sustainability to the bottom line of the company.

\section{References}

Akhtaruddin, M., Hossain, M. A., Hossain, M., \& Yao, L. (2009). Corporate Governance and Voluntary Disclosure in Corporate Annual Reports of Malaysian Listed Firms. Journal of Applied Management Accounting Research, 7(1), 1-20.

Al-Shaer, H., \& Zaman, M. (2016). Board Gender Diversity and Sustainability Reporting Quality. Journal of Contemporary Accounting \& Economics, 12(3), 210-222. http://doi.org/10.1016/j.jcae.2016.09.001

Allison, P. D. (1994). Using Panel Data to Estimate the Effects of Events. Sociological Methods \& Research, 23(2), 174-199. http://doi.org/10.1177/0049124194023002002

Arayssi, M., Dah, M., \& Jizi, M. (2016). Women on Boards, Sustainability Reporting and Firm Performance. Sustainability Accounting, Management and Policy Journal, 7(3), 376-401. http://doi.org/10.1108/SAMPJ-072015-0055

Arfken, D. E., Bellar, S. L., \& Helms, M. M. (2004). The Ultimate Glass Ceiling Revisited: The Presence of Women on Corporate Boards. Journal of Business Ethics, 50(2), 177-186. http://doi.org/10.1023/B:BUSI.0000022125.95758.98 
Bear, S., Rahman, N., \& Post, C. (2010). The Impact of Board Diversity and Gender Composition on Corporate Social Responsibility and Firm Reputation. Journal of Business Ethics, 97(2), 207-221. http://doi.org/10.1007/s10551-010-0505-2

Ben-Amar, W., Chang, M., \& Mcllkenny, P. (2017). Board Gender Diversity and Corporate Response to Sustainability Initiatives: Evidence from the Carbon Disclosure Project. Journal of Business Ethics, 142(2), 369-383. http://doi.org/10.1007/s10551-015-2759-1

Bernardi, R. A., Bosco, S. M., \& Vassill, K. M. (2006). Does Female Representation on Boards of Directors Associate With Fortune 's "100 Best Companies to Work For" List? Business \& Society, 45(2), 235-248. http://doi.org/10.1177/0007650305283332

Brüderl, J., \& Ludwig, V. (2015). Fixed-Effects Panel Regression. In H. Best \& C. Wolf (Eds.), The SAGE Handbook of Regression Analysis and Causal Inference (pp. 327-357). SAGE Publications Ltd.

Cabeza-García, L., Fernández-Gago, R., \& Nieto, M. (2017). Do Board Gender Diversity and Director Typology Impact CSR Reporting? European Management Review. http://doi.org/10.1111/emre.12143

Carter, D. A., Simkins, B. J., \& Simpson, W. G. (2003). Corporate Governance, Board Diversity, and Firm Value. The Financial Review, 38(1), 33-53. http://doi.org/10.1111/1540-6288.00034

Cheng, E. C. M., \& Courtenay, S. M. (2006). Board Composition, Regulatory Regime and Voluntary Disclosure. The International Journal of Accounting, 41(3), 262-289. http://doi.org/10.1016/j.intacc.2006.07.001

Cho, C. H., Michelon, G., Patten, D. M., \& Roberts, R. W. (2015). CSR Disclosure: The More Things Change...? Accounting, Auditing \& Accountability Journal, 28(1), 14-35. http://doi.org/10.1108/AAAJ-12-2013-1549

Conger, J. A., \& Lawler III, E. (2001). Building a High-Performing Board: How to Choose the Right Members. Business Strategy Review, 12(3), 11-19. http://doi.org/10.1111/1467-8616.00179

Deloitte. (2017). 2017 Board Diversity Survey: Seeing is Believing. Retrieved from https://www2.deloitte.com/content/dam/Deloitte/us/Documents/about-deloitte/us-about-boarddiversity-survey-seeing-is-believing.pdf

Eccles, R. G., Serafeim, G., \& Krzus, M. P. (2011). Market Interest in Nonfinancial Information. Journal of Applied Corporate Finance, 23(4), 113-127. http://doi.org/10.1111/j.1745-6622.2011.00357.x

Eulerich, M., Velte, P., \& Uum, C. van. (2014). The Impact of Management Board Diversity on Corporate Performance - An Empirical Analysis for the German Two-Tier System. Problems and Perspectives in Management, 12(1), 25-39.

Fernandez-Feijoo, B., Romero, S., \& Ruiz-Blanco, S. (2014). Women on Boards: Do They Affect Sustainability Reporting? Corporate Social Responsibility and Environmental Management, 21(6), 351-364. http://doi.org/10.1002/csr.1329

Ferreira, D. (2011). Board Diversity. In H. K. Baker \& R. Anderson (Eds.), Corporate Governance: A Synthesis of Theory, Research, and Practice (pp. 225-242). New Jersey: John Wiley \& Sons, Inc. http://doi.org/10.1002/9781118258439.ch12

Ferrero-Ferrero, I., Fernández-Izquierdo, M. Á., \& Muñoz-Torres, M. J. (2015). Integrating Sustainability into Corporate Governance: An Empirical Study on Board Diversity. Corporate Social Responsibility and Environmental Management, 22(4), 193-207. http://doi.org/10.1002/csr.1333

Frias-Aceituno, J. V., Rodriguez-Ariza, L., \& Garcia-Sanchez, I. . (2013). The Role of the Board in the Dissemination of Integrated Corporate Social Reporting. Corporate Social Responsibility and Environmental Management, 20(4), 219-233. http://doi.org/10.1002/csr.1294

Gangl, M. (2010). Causal Inference in Sociological Research. Annual Review of Sociology, 36(1), 21-47. http://doi.org/10.1146/annurev.soc.012809.102702 
Garcia-Torea, N., Fernandez-Feijoo, B., \& de la Cuesta, M. (2016). Board of Director's Effectiveness and the Stakeholder Perspective of Corporate Governance: Do Effective Boards Promote the Interests of Shareholders and Stakeholders? BRQ Business Research Quarterly, 19(4), 246-260. http://doi.org/10.1016/j.brq.2016.06.001

Ghani, E. K., Jamal, J., Puspitasari, E., \& Gunardi, A. (2018). Factors Influencing Integrated Reporting Practices Among Malaysian Public Listed Real Property Companies: A Sustainable Development Effort. International Journal of Managerial and Financial Accounting, 10(2), 144-162. http://doi.org/10.1504/IJMFA.2018.10012811

Gibson, K., \& O’Donovan, G. (2007). Corporate Governance and Environmental Reporting: an Australian study. Corporate Governance: An International Review, 15(5), 944-956. http://doi.org/10.1111/j.14678683.2007.00615.x

Guthrie, J. P., \& Parker, L. D. (1990). Corporate Social Disclosure Practice: A Comparative International Analysis. Advances in Public Interest Accounting, 3(159-175).

Habbash, M. (2016). Corporate Governance and Corporate Social Responsibility Disclosure: Evidence from Saudi Arabia. Social Responsibility Journal, 12(4), 740-754. http://doi.org/10.1108/SRJ-07-2015-0088

Hajek, A., Brettschneider, C., Lange, C., Posselt, T., Wiese, B., Steinmann, S., ... König, H.-H. (2015). Longitudinal Predictors of Institutionalization in Old Age. PLOS ONE, 10(12), e0144203. http://doi.org/10.1371/journal.pone.0144203

Halaby, C. N. (2003). Panel Models for the Analysis of Change and Growth in Life Course Studies. In J. T. Mortimer \& M. J. Shanahan (Eds.), Handbook of the Life Course (pp. 503-527). Boston, MA: Springer US. http://doi.org/10.1007/978-0-306-48247-2_23

Handajani, L., Subroto, B., Sutrisno, T., \& Saraswati, E. (2014). Does Board Diversity Matter on Corporate Social Disclosure? An Indonesian Evidence. Journal of Economics and Sustainable Development, 5(9), 8-16.

Haniffa, R. M., \& Cooke, T. E. (2002). Culture, Corporate Governance and Disclosure in Malaysian Corporations. Abacus, 38(3), 317-349. http://doi.org/10.1111/1467-6281.00112

Haniffa, R. M., \& Cooke, T. E. (2005). The Impact of Culture and Governance on Corporate Social Reporting. Journal of Accounting and Public Policy, 24(5), 391-430. http://doi.org/10.1016/j.jaccpubpol.2005.06.001

Hoang, T. C., Abeysekera, I., \& Ma, S. (2016). Board Diversity and Corporate Social Disclosure: Evidence from Vietnam. Journal of Business Ethics, 1-20. http://doi.org/10.1007/s10551-016-3260-1

Hsiao, C. (2003). Analysis of Panel Data (2nd ed.). Cambridge: Cambridge University Press.

Huijsmans, M. C. (2017). The Influence of Executive Board National Culture and Board Nationality Diversity on Corporate Social Performance in Western European Non-Financial Firms. Retrieved from http://www.divaportal.se/smash/get/diva2:1077895/FULLTEXT01.pdf

Hyun, E., Yang, D., Jung, H., \& Hong, K. (2016). Women on Boards and Corporate Social Responsibility. Sustainability, 8(4), 300. http://doi.org/10.3390/su8040300

IIRC. (2011). Towards Integrated Reporting: Communicating Value in the 21st Century.

Ioannou, I., \& Serafeim, G. (2015). The Impact of Corporate Social Responsibility on Investment Recommendations: Analysts' Perceptions and Shifting Institutional Logics. Strategic Management Journal, 36(7), 1053-1081. http://doi.org/10.1002/smj.2268

Jain, T., \& Jamali, D. (2016). Looking Inside the Black Box: The Effect of Corporate Governance on Corporate Social Responsibility. Corporate Governance: An International Review, 24(3), 253-273. http://doi.org/10.1111/corg.12154

Jizi, M. (2017). The Influence of Board Composition on Sustainable Development Disclosure. Business Strategy and the Environment, 26(5), 640-655. http://doi.org/10.1002/bse.1943 
Khan, H. (2010). The Effect of Corporate Governance Elements on Corporate Social Responsibility (CSR) Reporting: Empirical Evidence from Private Commercial Banks of Bangladesh. International Journal of Law and Management, 52(2), 82-109. http://doi.org/10.1108/17542431011029406

Kolk, A. (2008). Sustainability, Accountability and Corporate Governance: Exploring Multinationals' Reporting Practices. Business Strategy and the Environment, 17(1), 1-15. http://doi.org/10.1002/bse.511

Kolk, A., \& van Tulder, R. (2010). International Business, Corporate Social Responsibility and Sustainable Development. International Business Review, 19(2), 119-125. http://doi.org/10.1016/j.ibusrev.2009.12.003

Landry, E. E., Bernardi, R. A., \& Bosco, S. M. (2016). Recognition for Sustained Corporate Social Responsibility: Female Directors Make a Difference. Corporate Social Responsibility and Environmental Management, 23(1), 27-36. http://doi.org/10.1002/csr.1358

Lau, C., Lu, Y., \& Liang, Q. (2016). Corporate Social Responsibility in China: A Corporate Governance Approach. Journal of Business Ethics, 136(1), 73-87. http://doi.org/10.1007/s10551-014-2513-0

Leung, E. Y. W. (2015). Diversifying the Board - A Step Towards Better Governance. Retrieved from http://www.accaglobal.com/in/en/student/exam-support-resources/professional-exams-studyresources/p1/technical-articles/diversifying-the-board--a-step-towards-better-governance.html

Lincoln, A., \& Adedoyin, O. (2012). Corporate Governance and Gender Diversity in Nigerian Boardrooms. International Journal of Humanities and Social Sciences, 6(11), 3286-3292.

Maddala, G. S. (1987). Limited Dependent Variable Models Using Panel Data. The Journal of Human Resources, $22(3), 307-338$.

Malik, M. (2015). Value-Enhancing Capabilities of CSR: A Brief Review of Contemporary Literature. Journal of Business Ethics, 127(2), 419-438. http://doi.org/10.1007/s10551-014-2051-9

Mallin, C. (2004). Corporate Governance. Oxford: Oxford University Press.

Masulis, R. W., Wang, C., \& Xie, F. (2012). Globalizing the Boardroom - The Effects of Foreign Directors on Corporate Governance and Firm Performance. Journal of Accounting and Economics, 53(3), 527-554. http://doi.org/10.1016/j.jacceco.2011.12.003

Michelon, G., \& Parbonetti, A. (2012). The Effect of Corporate Governance on Sustainability Disclosure. Journal of Management \& Governance, 16(3), 477-509. http://doi.org/10.1007/s10997-010-9160-3

Monks, R. A. G., \& Minow, N. (2004). Corporate Governance (3rd ed.). Malden: Blackwell Publishers.

Nadeem, M., Zaman, R., \& Saleem, I. (2017). Boardroom Gender Diversity and Corporate Sustainability Practices: Evidence from Australian Securities Exchange Listed Firms. Journal of Cleaner Production, 149, 874-885. http://doi.org/10.1016/j.jclepro.2017.02.141

Nekhili, M., Nagati, H., Chtioui, T., \& Nekhili, A. (2017). Gender-Diverse Board and the Relevance of Voluntary CSR Reporting. International Review of Financial Analysis, 50, 81-100. http://doi.org/10.1016/j.irfa.2017.02.003

NSE. (2017). Industry Sectors. Retrieved from http://www.nse.com.ng/issuers/listing-your-company/industrysector

Nwannebuike, U. S., \& Ike, U. J. (2014). Accounting Profession and Corporate Governance in Nigeria: A Critical Review. International Journal of Managerial Studies and Research, 2(8), 94-102.

Okaro, S. C., \& Okafor, G. O. (2017). Integrated Reporting in Nigeria: The Present and Future. In M. Aluchna \& S. O. Idowu (Eds.), Responsible Corporate Governance: Towards Sustainable and Effective Governance Structures (pp. 247-263). Springer International Publishing. http://doi.org/10.1007/978-3-319-55206-4_13

Ong, T., \& Djajadikerta, H. G. (2017). Impact of Corporate Governance on Sustainability Reporting: Empirical Study in the Australian Resources Industry. In 8th Conference on Financial Markets and Corporate Governance. 
Post, C., Rahman, N., \& Rubow, E. (2011). Green Governance: Boards of Directors' Composition and Environmental Corporate Social Responsibility. Business \& Society, 50(1), 189-223. http://doi.org/10.1177/0007650310394642

Prado-Lorenzo, J.-M., Gallego-Alvarez, I., \& Garcia-Sanchez, I. M. (2009). Stakeholder Engagement and Corporate Social Responsibility Reporting: The Ownership Structure Effect. Corporate Social Responsibility and Environmental Management, 16(2), 94-107. http://doi.org/10.1002/csr.189

Prado-Lorenzo, J.-M., \& Garcia-Sanchez, I.-M. (2010). The Role of the Board of Directors in Disseminating Relevant Information on Greenhouse Gases. Journal of Business Ethics, 97(3), 391-424. http://doi.org/10.1007/s10551-010-0515-0

Rao, K., \& Tilt, C. (2016a). Board Composition and Corporate Social Responsibility: The Role of Diversity, Gender, Strategy and Decision Making. Journal of Business Ethics, 138(2), 327-347. http://doi.org/10.1007/s10551015-2613-5

Rao, K., \& Tilt, C. (2016b). Board Diversity and CSR Reporting: An Australian Study. Meditari Accountancy Research, 24(2), 182-210. http://doi.org/10.1108/MEDAR-08-2015-0052

Rao, K., Tilt, C. A., \& Lester, L. H. (2012). Corporate Governance and Environmental Reporting: An Australian Study. Corporate Governance: The International Journal of Business in Society, 12(2), 143-163. http://doi.org/10.1108/14720701211214052

Rodríguez-Ariza, L., García-Sánchez, I.-M., \& Frías-Aceituno, J.-V. (2012). The Role of the Board in Achieving Integrated Financial and Sustainability Reporting. In XV Encuentro AECA. Esposende.

Rupley, K. H., Brown, D., \& Marshall, R. S. (2012). Governance, Media and the Quality of Environmental Disclosure. Journal of Accounting and Public Policy, 31(6), 610-640. http://doi.org/10.1016/j.jaccpubpol.2012.09.002

Said, R., Zainuddin, Y. H., \& Haron, H. (2009). The Relationship Between Corporate Social Responsibility Disclosure and Corporate Governance Characteristics in Malaysian Public Listed Companies. Social Responsibility Journal, 5(2), 212-226. http://doi.org/10.1108/17471110910964496

Sánchez, I. G., Domínguez, L. R., \& Álvarez, I. G. (2011). Corporate Governance and Strategic Information on the Internet: A Study of Spanish Listed Companies. Accounting, Auditing \& Accountability Journal, 24(4), 471501. http://doi.org/10.1108/09513571111133063

Şener, i., \& Karaye, A. B. (2014). Board Composition and Gender Diversity: Comparison of Turkish and Nigerian Listed Companies. Procedia - Social and Behavioral Sciences, 150, 1002-1011. http://doi.org/10.1016/j.sbspro.2014.09.112

Setó-Pamies, D. (2015). The Relationship between Women Directors and Corporate Social Responsibility. Corporate Social Responsibility and Environmental Management, 22(6), 334-345. http://doi.org/10.1002/csr.1349

Seuring, S., \& Müller, M. (2008). Core Issues in Sustainable Supply Chain Management - A Delphi Study. Business Strategy and the Environment, 17(8), 455-466. http://doi.org/10.1002/bse.607

Sharif, M., \& Rashid, K. (2014). Corporate Governance and Corporate Social Responsibility (CSR) Reporting: An Empirical Evidence from Commercial Banks (CB) of Pakistan. Quality \& Quantity, 48(5), 2501-2521. http://doi.org/10.1007/s11135-013-9903-8

Sharma, S., \& Henriques, I. (2005). Stakeholder Influences on Sustainability Practices in the Canadian Forest Products Industry. Strategic Management Journal, 26(2), 159-180. http://doi.org/10.1002/smj.439

Ujunwa, A., Nwakoby, I., \& Ugbam, C. O. (2012). Corporate Board Diversity and Firm Performance: Evidence from Nigeria. Corporate Ownership \& Control, 9(2), 216-226.

Velte, P. (2017). Does Board Composition Have an Impact on CSR Reporting? Problems and Perspectives in Management, 15(2), 19-35. 
Walls, J. L., Berrone, P., \& Phan, P. H. (2012). Corporate Governance and Environmental Performance: Is There Really A Link? Strategic Management Journal, 33(8), 885-913. http://doi.org/10.1002/smj.1952

Webb, E. (2004). An Examination of Socially Responsible Firms' Board Structure. Journal of Management and Governance, 8(3), 255-277. http://doi.org/10.1007/s10997-004-1107-0

Yasser, Q. R., Al Mamun, A., \& Ahmed, I. (2017). Corporate Social Responsibility and Gender Diversity: Insights from Asia Pacific. Corporate Social Responsibility and Environmental Management, 24(3), 210-221. http://doi.org/10.1002/csr.1400

Zhang, J. Q., Zhu, H., \& Ding, H. (2013). Board Composition and Corporate Social Responsibility: An Empirical Investigation in the Post Sarbanes-Oxley Era. Journal of Business Ethics, 114(3), 381-392. http://doi.org/10.1007/s10551-012-1352-0 